\title{
THERMOECONOMIC ANALYSIS OF BIOGAS ENGINES POWERED COGENERATION SYSTEM
}

\author{
N. Doseva ${ }^{1,{ }^{*}}$, D. Chakyrova
}

\begin{abstract}
This study presents an analysis of an existing biogas engines-powered cogeneration system installed in Varna Wastewater Treatment Plant, Bulgaria using thermoeconomic method. The thermoeconomic analysis is conducted using three different groups of environmental conditions. The SPECO (specific exergy cost) method is applied to the system and cost balance equations are formulated for each component. The fuel $F$ and the product $P$ rules are used to obtain auxiliary equations. Moreover, in this paper, various thermoeconomic performance parameters such as the cost of exergy destruction, the relative cost difference and the exergoeconomic factor are determined. The obtained results show that the specific unit exergetic cost of the electrical power produced by the cogeneration system are found to be $30.0 € / \mathrm{GJ}=0.11 € / \mathrm{kWh}$, while the conducted thermoeconomic analysis based on energy delivers a result of $0.19 € / \mathrm{kWh}$ for the electrical work produced by biogas engines. In addition, the obtained results are compared to those seen in similar studies.
\end{abstract}

\section{Keywords: Biogas Engine, Cogeneration, Exergy, Thermoeconomics}

\section{INTRODUCTION}

Growing interest about energy efficiency of thermal systems has led to the presence of many studies dealing with development of methodologies for cost allocation and thermoeconomic optimization of energy conversion systems. Some authors [1-4] introduce energy as a base for assessment and monetary cost calculations. Nevertheless, analyses based on firs law of thermodynamics are inadequate for evaluating some features of energy resource utilization $[5,6]$. Therefore, this paper claims that if the objective is optimization, specifying the saving opportunities (i.e. energy audit) or determining of unit product cost of an installation, a detailed study of thermodynamic irreversibilities occurring within system components should be carried out.

Some researches including [7], [8] and [9] conducted thermoeconomic analysis of diesel engine powered cogeneration (CHP) systems. Surveys such as that performed by Cavalcanti and Motta [10] and Tempesti et al. [11] examined the relationship between monetary unit costs and exergy destruction of CHP systems with integrated renewable energy resources. Trigeneration systems are investigated from thermoeconomic point of view by Palomino and Nebra [12], Temir and Bilge [13], and Balli and Aras [14]. A large and growing body of literature has investigated gas and steam turbine based cogeneration systems [15-17]. In recent years, an increasingly studies reported results of the thermoeconomic performance parameters of biomass burned CHP systems [18-22].

Although a recent study by Abusoglu et al.[23] investigated a similar to this cogeneration system, it can be argued that there is an area required applying of the thermoeconomic methodologies to the combined heat and power system fueled biofuels. Furthermore, in reviewing the literature, no surveys was found on thermoeconomic performance parameters of CHP systems located in Bulgaria, and an undeniable fact is that the thermoeconomic analysis, especially the optimum between thermodynamic and economic parameters, immediately depends on the system location.

Therefore, this paper seeks to remedy the highlighted gap of knowledge in the field of the study by conducting the thermoeconomic evaluation based on exergy analysis with economic principles of the biogas engines powered CHP system. Thus, it is possible to explain the process of cost formation of products and, then, to formulate the theoretical framework of the procedures for exergy saving and optimization. 


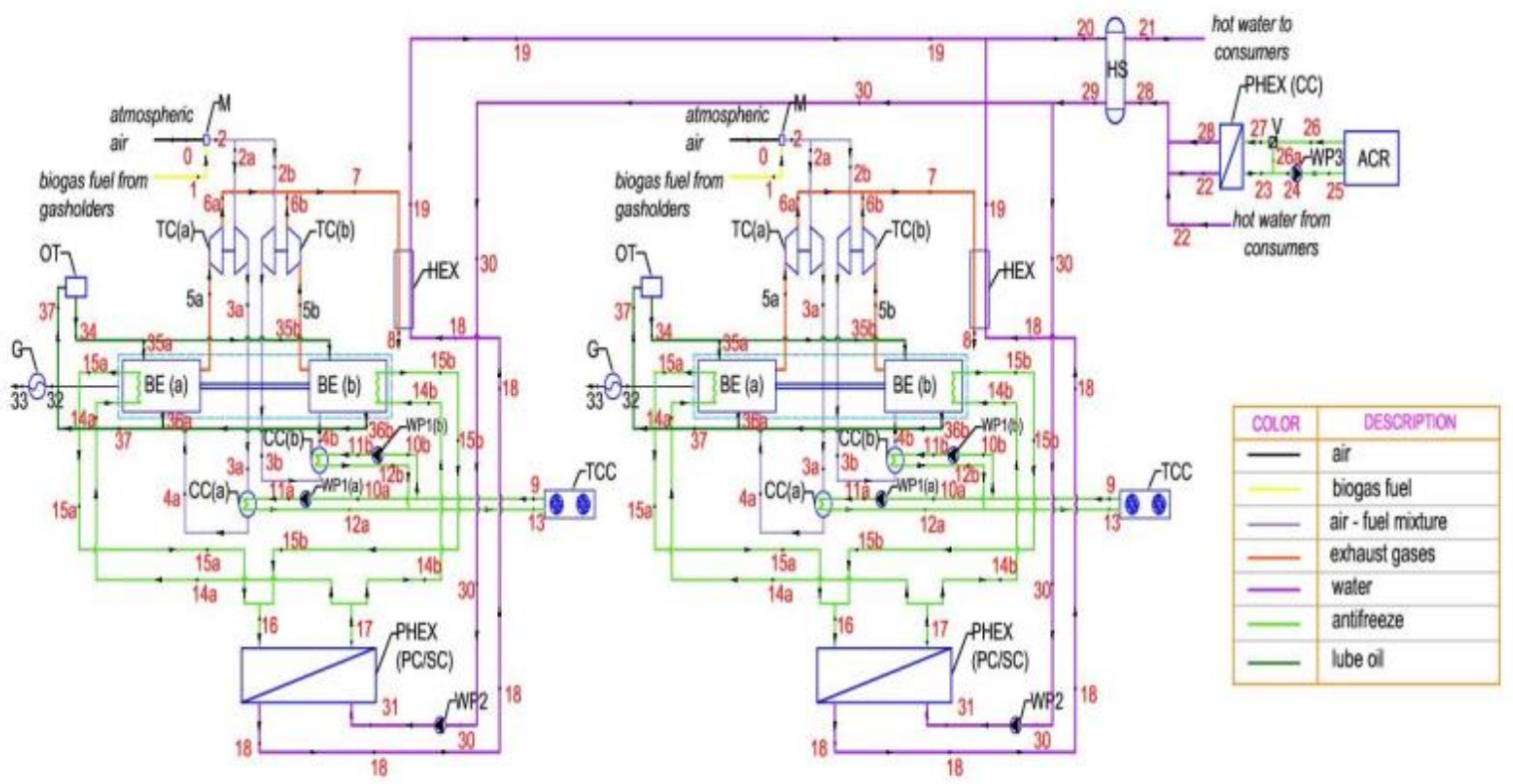

Figure 1. A schematic representation of the analyzed cogeneration system

$\mathrm{M}$ - mixer; TC(a), TC(b) - turbochargers; $\mathrm{BE}(\mathrm{a}), \mathrm{BE}(\mathrm{b})$ - internal combustion engines; $\mathrm{CC}(\mathrm{a}), \mathrm{CC}(\mathrm{b})$ - charge coolers; WP1(a), WP1(b) - technological circuit water pumps; TCC - technological circuit cooler; PHEX PC/SC - plate heat exchanger from secondary circuit; WP2 - secondary circuit water pump; HEX - heat exchanger; G - generator, OT oil tank; HS - hydraulic separator; PHEX (CC) - plate heat exchanger from cooling circuit; V - 3 -way valve; WP3 cooling circuit water pump; ACR - air - cooled radiator.

For this purpose, the paper begins by formulating of the cost rate balances for each component of the cogeneration system separately by applying of the SPECO method. It will then go on to determining of various thermoeconomic performance parameters, such as exergoeconomic factor, relative cost difference and cost rate of exergy destruction. Finally, the results obtained from thermoeconomic analysis are compared with those from traditional economic cost analysis.

Conducting the introduced methodology for thermoeconomic analysis of a cogeneration system driven by biogas engines, it is possible to get a notion about the real picture of the products costs of the system, that are observed on the Bulgarian market. The results of the current investigation, as well as the availability of the similar systems operating in various Bulgarian wastewater treatment plants creates the possibility to launching the work out strategies for the sustainable development of biogas technology in Bulgaria, based on real data.

\section{DESCRIPTION OF THE SYSTEM}

This study is made for a cogeneration plant driven by biogas internal combustion engines (ICE) and its purpose is to utilize the methane produced as a by-product of the sludge stabilization process at Varna Wastewater Treatment Plant (Varna WWTP) (Figure 2). The plant consists of two CHP modules, each of which is driven by ICE burned biogas - model Cento T300 SP BIO+ZP (Tedom) (Figure 1). The plant produced electrical energy and hot water. The electricity is generated by two, biogas engine actuated generator set. Each of the biogas engines - generators sets produce $320 \mathrm{~kW}$ electricity at $100 \%$ load. The current thermoeconomic model of the cogeneration plant was made for typical operation conditions of the system, namely $75 \%$ load. For these conditions the system produces $2 \times 240 \mathrm{~kW}$ electricity.

In the heat exchanger (HEX) of the plant, high temperature exhaust gas energy is used to heat water. Thus, the produced hot water has mass flow rate $7.6 \mathrm{~kg} / \mathrm{s}$. The heat energy consumption depends on thermal needs of mesophilic fermentation process, occurring within the digesters. Therefore, it seems that the thermoeconomic analysis should be conducted using different groups of ambient reference conditions. In current investigation, the temperature, pressure and relative humidity of the different dead (environmental) states are taken as follows: 


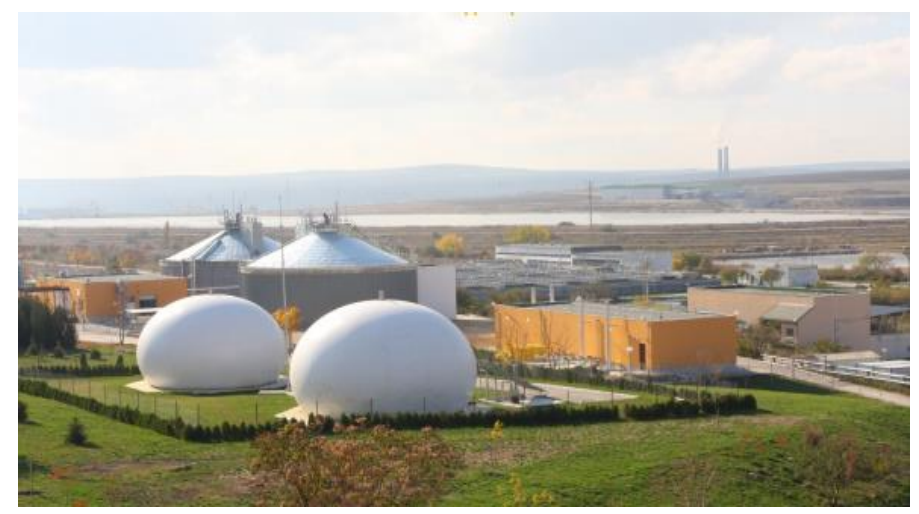

Figure 2. Biogas treatment and utilization system at Varna WWTP

- Summer operation condition of the system: $T_{0}=298.15 \mathrm{~K}, p_{0}=1.013 \mathrm{bar}$ and $\varphi_{0}=55 \%$;

- Spring - autumn operation condition of the system: $T_{0}=288.15 \mathrm{~K}, p_{0}=1.013 \mathrm{bar}$ and $\varphi_{0}=60 \%$;

- Winter operation condition of the system: $T_{0}=276.15 \mathrm{~K}, p_{0}=1.013 \mathrm{bar}$ and $\varphi_{0}=80 \%$.

\section{THERMOECONOMIC ANALYSIS OF THE BIOGAS POWERED COGENERATION SYSTEM}

In this study, the thermoeconomic analysis consists of the conventional exergy analysis and economic analysis. An aim of the performed here thermoeconomic analysis is to reveal the process of cost formation and assess unit exergy cost of product streams. This calls the use of cost rate balances formulated for each component of the cogeneration system separately.

For a unit operating in steady state, the cost rate balance is defined as given below [24, 26]:

$$
\sum_{e} \dot{C}_{e, k}+\dot{C}_{W, k}=\dot{C}_{q, k}+\sum_{i} \dot{C}_{i, k}+\dot{Z}_{k}
$$

where:

$$
\begin{gathered}
\dot{C}_{e}=c_{e} \dot{E} x_{e} \\
\dot{C}_{i}=c_{i} \dot{E} x_{i} \\
\dot{C}_{W}=c_{W} \dot{W} \\
\dot{C}_{q}=c_{q} \dot{E} x_{q}
\end{gathered}
$$

Therefore, the cost rate associated with exergy of the product, $\dot{C}_{P}$, is the sum of the cost rate associated with exergy of the fuel, $\dot{C}_{F}$, capital investment (CI) and operating and maintenance costs (O\&M).

The term $\dot{Z}_{k}$ is determined by first calculating the carrying charges (CC) and O\&M costs of the CHP system. This was performed in economic analysis of the plant [25]. After that are computed the levelized values of these expenditures per unit of time (hour) of system operation and associated with the $k$ th component using the following expression [24]:

$$
\dot{Z}_{k}=\dot{Z}_{k}^{C I}+Z_{k}^{O \& M}=\frac{C C_{L}+O \& M_{L}}{\tau} \cdot \frac{P E C_{k}}{\sum_{c o g e n} P E C}
$$


Applying Eq. (1) to the components of the system yields many unknowns and requires auxiliary equations to determine all cost per unit exergy entering and leaving control volumes of the system. These auxiliary equations are written according to the $F$ (Fuel) rule and $P$ (Product) rule [26] and along with the cost rate balances are presented in Table 1 .

\section{THERMOECONOMIC PERFORMANCE PARAMETERS FOR COMPONENT EVALUATION}

The thermoeconomic performance parameters include the cost of exergy destruction, the relative cost difference and the exergoeconomic factor. The approach used for determining of the thermoeconomic performance parameters is described in the following paragraphs.

Table 1. Cost rate balances and axially equation for the cogeneration system components

\begin{tabular}{|c|c|c|}
\hline Component & Control volume & Cost rate balances and auxiliary equations \\
\hline M & $0=$ & $\begin{array}{c}\dot{C}_{2}=\dot{C}_{0}+\dot{C}_{1}+\dot{Z}_{M} \\
c_{0}=0 \text { (Assumption) }\end{array}$ \\
\hline TCa,b & ${ }_{5 a, b}$ & $\begin{aligned} \dot{C}_{3 a, b}-\dot{C}_{2 a, b} & =\dot{C}_{5 a, b}-\dot{C}_{6 a, b}+\dot{Z}_{T C a, b} \\
\frac{\dot{C}_{2 a, b}}{\dot{E} x_{2 a, b}} & =\frac{\dot{C}_{3 a, b}}{\dot{E} x_{3 a, b}}(P-\text { rule })\end{aligned}$ \\
\hline $\mathrm{CCa}, \mathrm{b}$ & & $\begin{aligned} \dot{C}_{4 a, b}-\dot{C}_{3 a, b} & =\dot{C}_{11 a, b}-\dot{C}_{12 a, b}+\dot{Z}_{C C a, b} \\
\frac{\dot{C}_{3 a, b}}{\dot{E} x_{3 a, b}} & =\frac{\dot{C}_{4 a, b}}{\dot{E} x_{4 a, b}}(\text { F-rule })\end{aligned}$ \\
\hline WP1a,b & $w_{\text {natas }}$ & $\begin{array}{c}\dot{C}_{W, W P 1}+\dot{Z}_{W P 1}=\dot{C}_{11 a, b}-\dot{C}_{10 a, b} \\
c_{W, W P 1}=0.19 € / k W h \text { (Assumption) }\end{array}$ \\
\hline TCC & $\stackrel{13}{0^{\prime} 4 \quad \gamma^{0}}$ & $\begin{array}{r}\dot{C}_{9}+\dot{C}_{0^{\prime}}=\dot{C}_{13}+\dot{C}_{0}+\dot{Z}_{T C C} \\
\frac{\dot{C}_{13}}{\dot{E} x_{13}}=\frac{\dot{C}_{9}}{\dot{E} x_{9}}(F-\text { rule })\end{array}$ \\
\hline $\mathrm{BEa}, \mathrm{b}$ & $\begin{aligned} 4 a, b \rightarrow & \rightarrow \\
14 a, b & \rightarrow \\
35, b \rightarrow & \rightarrow\end{aligned}$ & $\begin{array}{l}\left(\dot{C}_{4 a, b}-\dot{C}_{5 a, b}\right)+\dot{Z}_{B E a, b}=\dot{C}_{W, 32}+\left(\dot{C}_{15 a, b}-\dot{C}_{14 a, b}\right)+\left(\dot{C}_{36 a, b}-\dot{C}_{35 a, b}\right)+ \\
+\dot{C}_{q, B E a, b} \\
c_{5 a, b}=c_{6 a, b}=c_{15 a, b}=c_{36 a, b} \quad(F-\text { rule })\end{array}$ \\
\hline OT & ${ }^{34}$ & $\dot{C}_{34}=\dot{C}_{37}+\dot{Z}_{O T}$ \\
\hline PHEX PS/SC & $16 \rightarrow$ & $\begin{array}{c}\dot{C}_{18}-\dot{C}_{31}=\dot{C}_{16}-\dot{C}_{17}+\dot{Z}_{P H E X(S C / P C)} \\
\frac{\dot{C}_{16}}{\dot{E} x_{16}}=\frac{\dot{C}_{17}}{\dot{E} x_{17}} \quad(F-\text { rule })\end{array}$ \\
\hline HEX & 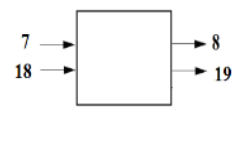 & $\begin{aligned} \dot{C}_{19}-\dot{C}_{18} & =\left(\dot{C}_{7}-\dot{C}_{8}\right)+\dot{Z}_{H E X} \\
\frac{\dot{C}_{7}}{\dot{E} x_{7}} & =\frac{\dot{C}_{8}}{\dot{E} x_{8}}(F-\text { rule })\end{aligned}$ \\
\hline WP2 & $\mathrm{W}_{\mathrm{a}_{2}}$ & $\begin{array}{c}\dot{C}_{W, W P 2}+\dot{Z}_{W P 2}=\dot{C}_{31}-\dot{C}_{30} \\
c_{W, W P 2}=0.19 € / k W h \text { (Assumption) }\end{array}$ \\
\hline HS & 29 & $\begin{array}{c}\dot{C}_{21}+\dot{C}_{29}=\dot{C}_{20}+\dot{C}_{28}+\dot{Z}_{H S} \\
\frac{\dot{C}_{29}}{\dot{E} x_{29}}=\frac{\dot{C}_{21}}{\dot{E} x_{21}} \quad(F-\text { rule })\end{array}$ \\
\hline WP3 & $\mathbf{W}_{\mathrm{n}}$ & $\begin{array}{c}\dot{C}_{W, W P 3}+\dot{Z}_{W P 3}=\dot{C}_{25}-\dot{C}_{24} \\
c_{W, W P 2}=0.19 € / k W h \text { (Assumption) }\end{array}$ \\
\hline
\end{tabular}


Journal of Thermal Engineering, Research Article, Vol. 5, No. 2, Special Issue 9, pp. 93-107, February, 2019

Table 1. (Cont.) Cost rate balances and axially equation for the cogeneration system components

\begin{tabular}{|c|c|c|}
\hline ACR & $22 \rightarrow{\stackrel{1}{1} \quad 4^{0^{\prime \prime}}}^{\longrightarrow}-28$ & $\begin{array}{c}\dot{C}_{26}+\dot{C}_{0^{\prime \prime}}=\dot{C}_{25}+\dot{C}_{0}+\dot{Z}_{A C R} \\
\frac{\dot{C}_{25}}{\dot{E} x_{25}}=\frac{\dot{C}_{26}}{\dot{E} x_{26}}(\text { F-rule })\end{array}$ \\
\hline $\begin{array}{c}\text { PHEX } \\
\text { CC }\end{array}$ & $\stackrel{22}{27} \rightarrow$ & $\begin{array}{c}\dot{C}_{28}+\dot{C}_{23}=\dot{C}_{22}+\dot{C}_{27}+\dot{Z}_{\text {PHEX }(C C)} \\
\frac{\dot{C}_{22}}{\dot{E} x_{22}}=\frac{\dot{C}_{28}}{\dot{E} x_{28}} \quad(F-\text { rule })\end{array}$ \\
\hline V & $\begin{array}{l}\stackrel{26}{\longrightarrow}-{ }^{23}-{ }^{24} \\
-\end{array}$ & $\begin{array}{c}\dot{C}_{26}+\dot{C}_{23}+\dot{Z}_{V}=\dot{C}_{27}+\dot{C}_{24} \\
\frac{\dot{C}_{26}}{\dot{E} x_{26}}=\frac{\dot{C}_{23}}{\dot{E} x_{23}}(F-\text { rule })\end{array}$ \\
\hline $\mathrm{G}$ & $32-\bigcap^{33}$ & $\dot{C}_{W, 32}+\dot{Z}_{G}=\dot{C}_{W, 33}=c_{W} \dot{W}_{33}$ \\
\hline
\end{tabular}

The thermoeconomic performance parameters include the cost of exergy destruction, the relative cost difference and the exergoeconomic factor. The approach used for determining of the thermoeconomic performance parameters is described in the following paragraphs.

In cost rate balances formulated for the cogeneration system components (Table 1), there is no term directly associated with exergy destruction, i.e. the cost rate of exergy destruction is hidden cost and it can be determine only by thermoeconomic evaluation on component level. According to the assumptions made in this paper, the cost rate of exergy destruction of the $k$ th component can be defined by [24], [26]:

$$
\dot{C}_{D, k}=c_{F, k} \dot{E} x_{D, k}
$$

Another parameter determined in this study is the relative cost difference, $r$. This variable expresses the relative increase in the unit exergy cost between fuel and product of the component and it is defined by [24, 26]:

$$
r_{k}=\frac{c_{P, k}-c_{F, k}}{c_{F, k}}
$$

In evaluating the thermoeconomic performance of a component, it is useful to know the contribution of the non-exergy related cost (CI and O\&M costs) to the total cost increase. This is provided by the exergoeconomic factor represented by the following equation [24], [26]:

$$
f_{k}=\frac{\dot{Z}_{k}}{\dot{Z}_{k}+c_{F, k}\left(\dot{E} x_{D, k}+\dot{E} x_{L, k}\right)}
$$

\section{RESULTS AND DISCUSSION}

In this study, the SPECO method is applied to an existing CHP system which uses biogas engines. The following assumptions were made during the analysis:

(i) The CHP system and its components operate at steady state;

(ii) The exergy flow rates ( $\dot{E} x_{e}, \dot{W}_{k}, \dot{E} x_{q, k}$ and $\dot{E} x_{i}$ ) exiting and entering the $k$ th component of the CHP system are calculated in another study conducted by authors [6]. It was conducted error analysis of the thermodynamic model, comparing the measured and obtained numerical data at some states of the system [25];

(iii) The annual carrying charges and operating and maintenance costs are apportioned among the system components according to the contribution of each component to the sum of purchased-equipment costs [24];

(iv) A zero unit cost is assumed for air entering mixer (M); 
(v) The average unit cost of the electrical energy entering water pumps (WP1a,b; WP2 and WP3) and the water entering the CHP system is assumed according to the current prices of electricity distribution company and municipal water and sewage department, respectively;

(vi) The exergy of product $\left(\dot{E} x_{P, k}\right)$ is fixed and the unit cost of fuel $\left(c_{F, k}\right)$ of the $k$ th component is independent of the exergy destruction.

According to assumption (ii) and Eq.(6), the term $\dot{Z}_{k}$ is calculated with the assistance of the annual levelized carrying charges (CC), O\&M costs and total purchased equipment cost (PEC) of the CHP system and its components. Using the data published in another investigation [25], the hourly levelized CC and O\&M costs are $247610.44 €$ and $30181 €$, respectively. Furthermore, the total annual number hours of system operation at $75 \%$ load $(\tau)$, the life time of the system $(n)$ and capital recovery factor (CRF) are taken as $5256 \mathrm{~h}, 20 \mathrm{yr}$ and 0.07708 , respectively [25]. The hourly levelized total costs of the $k$ th system component are presented in Figure 3 and Table 2.

Annual fuel cost rate of biogas, $F C_{L}$, is calculated by Doseva, N. [25] to be $151982.90 € /$ yr. On exergetic base, the hourly levelized fuel cost rates is $28.82 € / \mathrm{h}$. The average unit exergy cost of total fuel entering a CHP module, $c_{1}$, is calculated as $0.022 € / \mathrm{kWh}$.

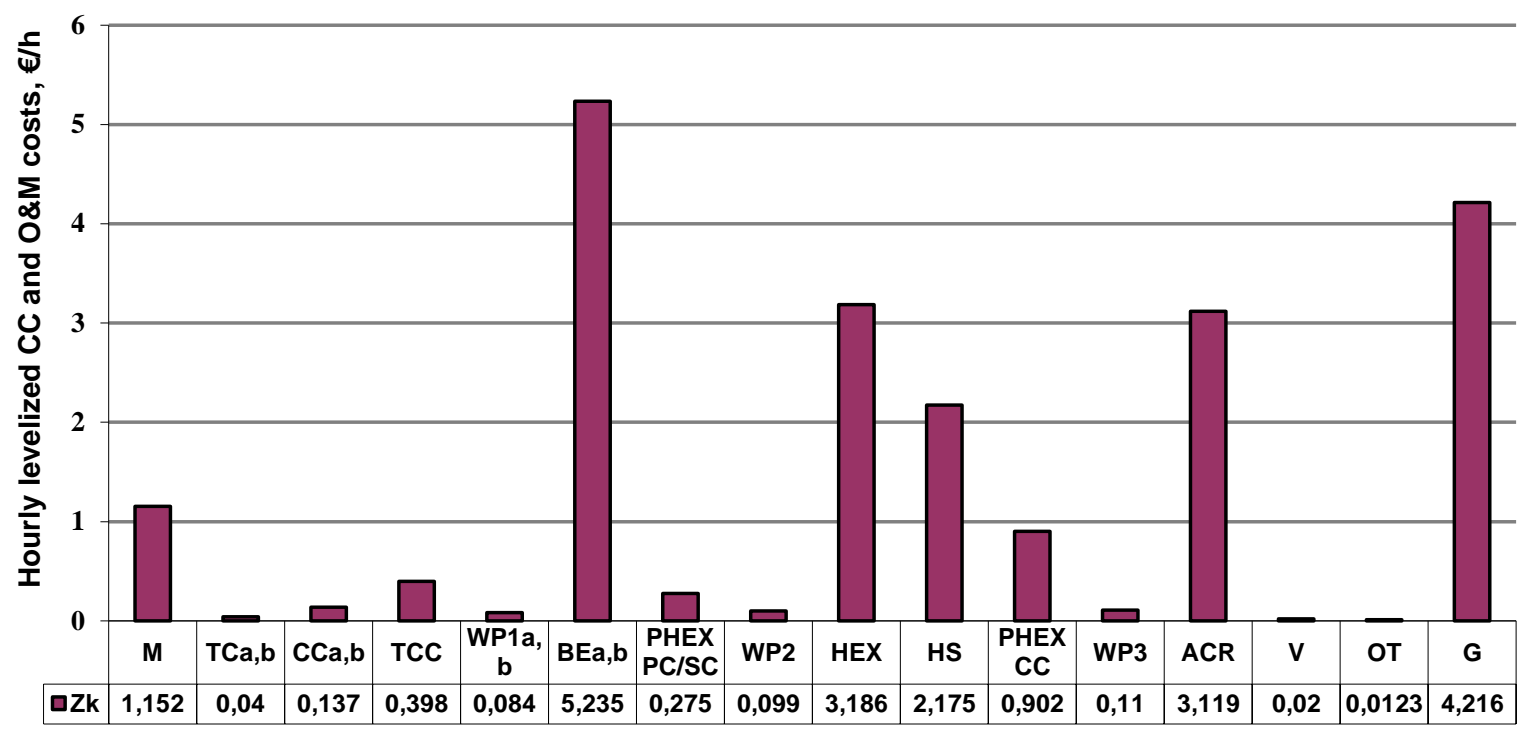

\section{CHP system components}

Figure 3. Cost rate associated with the sum of carrying charges and O\&M of the cogeneration system components

From Figure 3 and Table 2 is clear that the biogas engines, the generator and the air-cooled radiator are components with the higher value of the parameter $\dot{Z}_{k}$ due to high values of the hourly levelized carrying charges and O\&M costs of the components.

Using Eq. (1) and $P$ - and $F$-rule [26] to each system component lead to system of linear equations and unknowns indicated by equations in Table 1 . This system of linear equations is solved to obtain the cost per unit exergy associated with each stream of the cogeneration system. The obtained results at the summer operating condition of the CHP system are presented in Table 2 and a cost flow diagram of the part of the system is shown in Figure 5. 
Journal of Thermal Engineering, Research Article, Vol. 5, No. 2, Special Issue 9, pp. 93-107, February, 2019

Table 2. Cost per unit of exergy and cost rates of the system flows at the summer operation condition of the system $\left(T_{0}=298.15 K, p_{0}=1.013 b a r\right.$ and $\left.\varphi_{0}=55 \%\right)$

\begin{tabular}{|c|c|c|c|c|}
\hline \multicolumn{5}{|c|}{$\operatorname{Mixer}(\mathrm{M}) \quad \dot{Z}_{M}=1.152 € / \mathrm{h}$} \\
\hline № & Stream & $\dot{E x}, \mathrm{GJ} / \mathrm{h}$ & $c, € / \mathrm{GJ}$ & $\dot{C}, € / \mathrm{h}$ \\
\hline 0 & Air & 0 & 0 & 0 \\
\hline 1 & Biogas & 2.395 & 6.11 & 14.63 \\
\hline 2 & Air-fuel mixture & 2.382 & 6.67 & 15.88 \\
\hline \multicolumn{5}{|c|}{ Turbochargers (TCa,b) $\quad \dot{Z}_{T C a, b}=0.05 € / h$} \\
\hline $2 a, b$ & Air-fuel mixture & 1.191 & 6.67 & 7.94 \\
\hline $3 a, b$ & Air-fuel mixture & 1.257 & 6.67 & 8.38 \\
\hline $5 a, b$ & Exhaust gases & 0.458 & 4.44 & 2.04 \\
\hline $6 a, b$ & Exhaust gases & 0.370 & 4.44 & 1.65 \\
\hline \multicolumn{5}{|c|}{ Charge coolers $(\mathrm{CCa}, \mathrm{b}) \quad \dot{Z}_{C C a, b}=0.137 € / \mathrm{h}$} \\
\hline $3 a, b$ & Air-fuel mixture & 1.257 & 6.67 & 8.38 \\
\hline $4 a, b$ & Air-fuel mixture & 1.242 & 6.67 & 8.28 \\
\hline $11 \mathrm{a}, \mathrm{b}$ & Antifreeze & 38.207 & 44.53 & 1701.18 \\
\hline $12 \mathrm{a}, \mathrm{b}$ & Antifreeze & 38.215 & 44.53 & 1701.62 \\
\hline \multicolumn{5}{|c|}{ Technological circuit cooler (TCC) $\quad \dot{Z}_{T C C a, b}=0.398 € / \mathrm{h}$} \\
\hline 9 & Antifreeze & 76.413 & 44.53 & 509.42 \\
\hline 13 & Antifreeze & 76.430 & 44.53 & 509.54 \\
\hline 0 & Air & 0.026 & 8.33 & 1.16 \\
\hline $0^{\prime}$ & Air & 0.033 & 45.28 & 1.46 \\
\hline \multicolumn{5}{|c|}{ Water pumps $\left(\right.$ WP1a,b) $\dot{Z}_{W P 1 a, b}=0.084 € / \mathrm{h}$} \\
\hline $10 \mathrm{a}, \mathrm{b}$ & Antifreeze & 38.207 & 44.52 & 1701.12 \\
\hline $11 \mathrm{a}, \mathrm{b}$ & Antifreeze & 38.207 & 44.53 & 1701.18 \\
\hline & Mechanical work & 0.002 & 53.06 & 0.11 \\
\hline \multicolumn{5}{|c|}{ Biogas engines (BEa,b) $\quad \dot{Z}_{B E a, b}=5.235 € / \mathrm{h}$} \\
\hline $4 a, b$ & Air-fuel mixture & 1.242 & 6.67 & 8.28 \\
\hline $14 a, b$ & Antifreeze & 19.853 & 4.47 & 88.79 \\
\hline $35 \mathrm{a}, \mathrm{b}$ & Lube oil & 0.004 & 13.89 & 0.05 \\
\hline $36 a, b$ & Lube oil & 0.009 & 4.47 & 0.04 \\
\hline $15 \mathrm{a}, \mathrm{b}$ & Antifreeze & 19.887 & 4.47 & 88.94 \\
\hline $5 \mathrm{a}, \mathrm{b}$ & Exhaust gases & 0.458 & 4.47 & 2.05 \\
\hline 32 & Mechanical work & 0.450 & 24.17 & 10.88 \\
\hline & Loss & 0.015 & 6.72 & 0.10 \\
\hline \multicolumn{5}{|c|}{ Plate heat exchanger PC/SC (PHEX PC/SC) $\dot{Z}_{P H E X}{ }_{P C / S C}=0.275 € / \mathrm{h}$} \\
\hline 16 & Antifreeze & 39.773 & 4.47 & 177.87 \\
\hline 17 & Antifreeze & 39.706 & 4.47 & 177.57 \\
\hline 18 & Water & 2.548 & 0.69 & 1.77 \\
\hline 31 & Water & 2.505 & 0.47 & 1.18 \\
\hline \multicolumn{5}{|c|}{ Water pump (WP2) $\dot{Z}_{W P 2}=0.099 € / \mathrm{h}$} \\
\hline 30 & Water & 2.505 & 0.42 & 1.04 \\
\hline 31 & Water & 2.505 & 0.47 & 1.18 \\
\hline & Mechanical work & 0.002 & 53.06 & 0.08 \\
\hline \multicolumn{5}{|c|}{ Heat exchanger $(\mathrm{HEX}) \dot{Z}_{H E X}=3.186 € / \mathrm{h}$} \\
\hline 7 & Exhaust gases & 0.740 & 4.47 & 3.31 \\
\hline 8 & Exhaust gases & 0.507 & 4.47 & 2.27 \\
\hline 18 & Water & 2.548 & 0.69 & 1.77 \\
\hline 19 & Water & 2.654 & 2.29 & 6.09 \\
\hline
\end{tabular}


Table 2. (Cont.) Cost per unit of exergy and cost rates of the system flows at the summer operation condition of the system

\begin{tabular}{|c|c|c|c|c|}
\hline \multicolumn{5}{|c|}{ Hydraulic separator $(\mathrm{HS}) \quad \dot{Z}_{H S}=2.175 € / \mathrm{h}$} \\
\hline 20 & Water & 5.307 & 2.29 & 12.18 \\
\hline 28 & Water & 4.632 & 0.42 & 1.93 \\
\hline 21 & Water & 4.926 & 2.85 & 14.03 \\
\hline 29 & Water & 5.009 & 0.42 & 2.09 \\
\hline \multicolumn{5}{|c|}{ Plate heat exchanger CC (PHEX CC) $\dot{Z}_{P H E X}{ }_{C C}=0.902 € / h$} \\
\hline 22 & Water & 4.737 & 0.42 & 1.97 \\
\hline 28 & Water & 4.632 & 0.42 & 1.93 \\
\hline 27 & Antifreeze & 252.454 & 11.23 & 2835.97 \\
\hline 23 & Antifreeze & 252.512 & 11.23 & 2836.76 \\
\hline \multicolumn{5}{|c|}{ Water pump (WP3) $\dot{Z}_{\boldsymbol{W P 3}}=\mathbf{0 . 1 1} € / \mathrm{h}$} \\
\hline 24 & Antifreeze & 534.046 & 11.23 & 5998.37 \\
\hline 25 & Antifreeze & 534.046 & 11.23 & 5998.67 \\
\hline & Mechanical work & 0.004 & 53.06 & 0.21 \\
\hline \multicolumn{5}{|c|}{ Air - cooled radiator $(\mathrm{ACR}) \quad \dot{Z}_{A C R}=3.119 € / \mathrm{h}$} \\
\hline 25 & Antifreeze & 534.046 & 11.23 & 5998.67 \\
\hline 26 & Antifreeze & 533.996 & 11.23 & 5998.11 \\
\hline 0 & Air & 0.025 & 8.33 & 0.21 \\
\hline $0^{\prime \prime}$ & Air & 0.029 & 133.06 & 3.89 \\
\hline \multicolumn{5}{|c|}{ 3-way valve $(\mathrm{V}) \quad \dot{Z}_{V}=0.020 € / \mathrm{h}$} \\
\hline 26 & Antifreeze & 533.996 & 11.23 & 5998.11 \\
\hline 27 & Antifreeze & 252.454 & 11.23 & 2835.97 \\
\hline 23 & Antifreeze & 252.512 & 11.23 & 2836.76 \\
\hline 24 & Antifreeze & 534.046 & 11.23 & 5998.37 \\
\hline \multicolumn{5}{|c|}{ Oil tank (OT) $\quad \dot{Z}_{O T}=0.023 € / h$} \\
\hline 37 & Lube oil & 0.018 & 4.47 & 0.08 \\
\hline 34 & Lube oil & 0.007 & 13.89 & 0.10 \\
\hline \multicolumn{5}{|c|}{ Generator $(G) \quad \dot{Z}_{G}=4.216 € / h$} \\
\hline 32 & Mechanical work & 0.900 & 24.14 & 21.73 \\
\hline 33 & Electrical energy & 0.864 & 30.00 & 25.92 \\
\hline
\end{tabular}

Table 2 is quite revealing in several ways. First, the obtained data demonstrate that the unit exergy cost of the net electrical power produced by the CHP system at the summer operating conditions of the CHP system ( $T_{0}=298.15 \mathrm{~K}, p_{0}=1.013 \mathrm{bar}$ and $\left.\varphi_{0}=55 \%\right)$ is $30.0 € / \mathrm{GJ}=0.11 € / \mathrm{kWh}$, while the same cost of the by-product (thermal energy) is $0.42 € / G J$. Moreover, as can be seen from the table above, the cost flow rate associated with gases leaving the heat exchanger (HEX) and exhaust to the environment is $2.27 € / \mathrm{h}$.

Figure 4 compares the obtained results of the unit exergy cost of the produced net electrical energy at the considered different groups of ambient reference conditions. This figure seems to show generally closer values. On the other hand, there is a trend of decreasing of the unit exergy cost of produced electricity with declining of the ambient temperature. These results may be explained by the fact that the exergy efficiency of the CHP system slowly increase with decreasing of the reference temperature [25].

To verify the results of calculation of the flow costs of the system, some previous studies are reviewed. The data obtained in these studies is listed in Table 3.

Table 3 shown that there are similarities between the unit exergy cost of the net electrical power produced by the CHP system calculated in this study and this presented by Abusoglu et al. [23]. Although the cited paper also investigates the process of cost formation of the products of a biogas engine powered CHP system, the slight difference in the exergy costs is due to variation of the fuel price, the power capacity of system, the type and purchased cost of equipment and the system location 


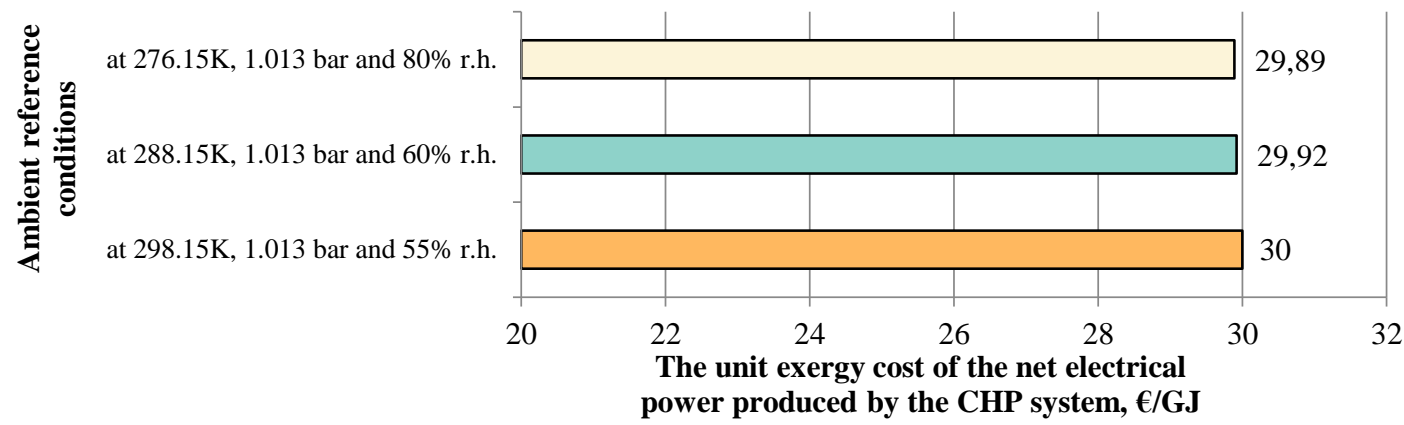

Figure 4. Comparison of results of the unit exergy cost of the produced net electrical energy at the considered different groups of ambient reference conditions

Table 3. Results obtained in similar studies

\begin{tabular}{|c|c|c|}
\hline Exergy costs & Type of CHP system & Reference \\
\hline \multicolumn{3}{|c|}{ Engine driven CHP systems } \\
\hline $\begin{array}{l}\text { Electricity: } \\
0.03 € / \mathrm{kWh}\end{array}$ & Diesel engine powered CHP system installed in Turkey & [7] \\
\hline Electricity: $0.13 € / \mathrm{kWh}$ & $\begin{array}{c}\text { Micro CHP system based on an Ericsson engine and } \\
\text { located in France }\end{array}$ & [27] \\
\hline \multicolumn{3}{|c|}{ Turbine driven CHP systems } \\
\hline $\begin{array}{c}\text { Electricity: } 0.07 € / \mathrm{kWh} \\
\text { Heat: } 0.02 € / \mathrm{kWh}\end{array}$ & Micro GT CHP system burned natural gas & [15] \\
\hline $\begin{array}{c}\text { Electricity: } 0.08 € / \mathrm{kWh} \\
\text { Heat: } 0.02 € / \mathrm{kWh}\end{array}$ & Micro GT-ORC CHP system burned natural gas & [15] \\
\hline $\begin{array}{c}\text { Electricity: } 0.06 € / \mathrm{kWh} \\
\text { Heat: } 0.05 € / \mathrm{kWh}\end{array}$ & GT CHP system located in Turkey & [16] \\
\hline $\begin{array}{l}\text { Electricity: } 0.1 / \mathrm{kWh} \\
\text { Heat: } 0.03 € / \mathrm{kWh}\end{array}$ & Micro GT CHP system situated in Turkey & [28] \\
\hline Electricity: $0.07 € / \mathrm{kWh}$ & GT / ST CHP system installed in Turkey & [29] \\
\hline $\begin{array}{c}\text { Electricity: } \\
\text { GT: } 0.05 € / \mathrm{kWh} ; \mathrm{ST}: \\
0.12 € / \mathrm{kWh} \\
\text { Average: } 0.0622 € / \mathrm{kWh}\end{array}$ & GT / ST CHP system installed in Turkey & [17] \\
\hline $\begin{array}{l}\text { Electricity: } \\
0.09 € / \mathrm{kWh}\end{array}$ & Rankine power cycle (ST CHP system) & [30] \\
\hline $\begin{array}{l}\text { Electricity: } \\
0.05 € / \mathrm{kWh}\end{array}$ & GT CHP at $100 \%$ load with an electricity output $1000 \mathrm{~kW}$ & [31] \\
\hline $\begin{array}{c}\text { Electricity: } \\
0.06 € / \mathrm{kWh} \\
\text { Heat: } 0.09 € / \mathrm{kWh}\end{array}$ & Base case GT CHP system (CGAM problem) & [24] \\
\hline \multicolumn{3}{|c|}{ CHP systems with integrated renewable energy resources } \\
\hline $\begin{array}{l}\text { Electricity: } 0.03 € / \mathrm{kWh} \\
\text { Heat: } 0.10 € / \mathrm{kWh}\end{array}$ & $\begin{array}{c}\text { Solar - powered / fuel assisted Rankine cycle for power } \\
\text { generation located in Brazil }\end{array}$ & [10] \\
\hline Electricity: $0.08 € / \mathrm{kWh}$ & Biogas engine powered CHP system & [23] \\
\hline $\begin{array}{l}\text { Electricity: } 0.05 € / \mathrm{kWh} \\
\quad \text { (at working fluid } \\
\text { R245fa in July) }\end{array}$ & $\begin{array}{l}\text { Micro CHP ORC system fuelled by two renewable energy } \\
\text { resources (solar and low-temperature geothermal) situated } \\
\text { in Italy }\end{array}$ & [11] \\
\hline $\begin{array}{l}\text { Electricity: } 0.21 € / \mathrm{kWh} \\
\text { Heat: } 0.20 € / \mathrm{kWh}\end{array}$ & ORC CHP system burned biomass & [19] \\
\hline \multicolumn{3}{|c|}{ Trigeneration systems } \\
\hline Electricity: $0.035 € / \mathrm{kWh}$ & $\begin{array}{c}\text { Tetra-combined trigeneration system developed by } \\
\text { Garagatti, Arriola and Olivera (2001) }\end{array}$ & [32] \\
\hline Electricity: $0.15 € / \mathrm{kWh}$ & Trigeneration system located in Turkey & [14] \\
\hline
\end{tabular}


Referring to the data in Table 3, a comparison of the unit cost of produced electricity with those of the other configurations cogeneration systems reveals the following: the unit exergy cost of electricity produced by gas turbine (GT) based cogeneration systems is with the range $0.05 € / \mathrm{kWh}-0.1 € / \mathrm{kWh}$, while the stream turbine (ST) based CHP systems are characterized by unit exergy cost of produces electrical power around $0.11 € / \mathrm{kWh}$ [17]. The unit exergy cost of produced electricity, however, declined sharply to $0.03 € / \mathrm{kWh}$ when a diesel engine based cogeneration systems is used [7] and it is scarcely smaller in case of external combustion engine powered CHP system [27]. An existing trigeneration system located in Turkey [14] has an exergy cost per unit produced electrical power amounting to $0.15 € / \mathrm{kWh}$ and it is somewhat bigger than the electricity cost of the analyzed system. In general, therefore, it seems that the investigated CHP system produces electrical power with price, which is competitive to others configurations CHP systems and those with integrated renewable energy resources.

The cost of exergy destruction, the relative cost difference and exergoeconomic factor of the CHP system components at the summer operating conditions of the CHP system $\left(T_{0}=298.15 K, p_{0}=1.013\right.$ bar and $\varphi_{0}=55 \%$ ) are calculated and represented in Table 4. From this data, we can see that components such as heat exchangers (PHEX CC, HEX, ACR and TCC) and water pumps (WP3, WP2 and WP1a,b) have very high values of the relative cost difference. These results may be explained by the fact that their values of the cost per unit exergy of the product are many times greater than the cost per unit exergy of the fuel due to high value of exergy destruction rate and low values of exergy efficiency for these components determined in another study [6]. This statement is somewhat confirmed by the exergoeconomic factor values. Among all the system components, it is noticeable that the heat exchangers (PHEX CC, HEX and ACR) have high values of exergoeconomic factor. The exergoeconomic factor results of PHEX CC, HEX and ACR may be explained by the fact that the investment and O\&M costs are greater than the costs rate of exergy destruction of these components, and the low values of cost rate of exergy destruction are caused by low exergy cost of the fuel. Not always, however, high values of $r_{k}$ lead to high value of $\mathrm{f}_{\mathrm{k}}$. An example of this is a case of the mixer $(\mathrm{M})$ - the relative cost difference is determined as $8.47 \%$ and it is one of the lowest values, while the exergoeconomic factor is calculated to be $95.53 \%$.

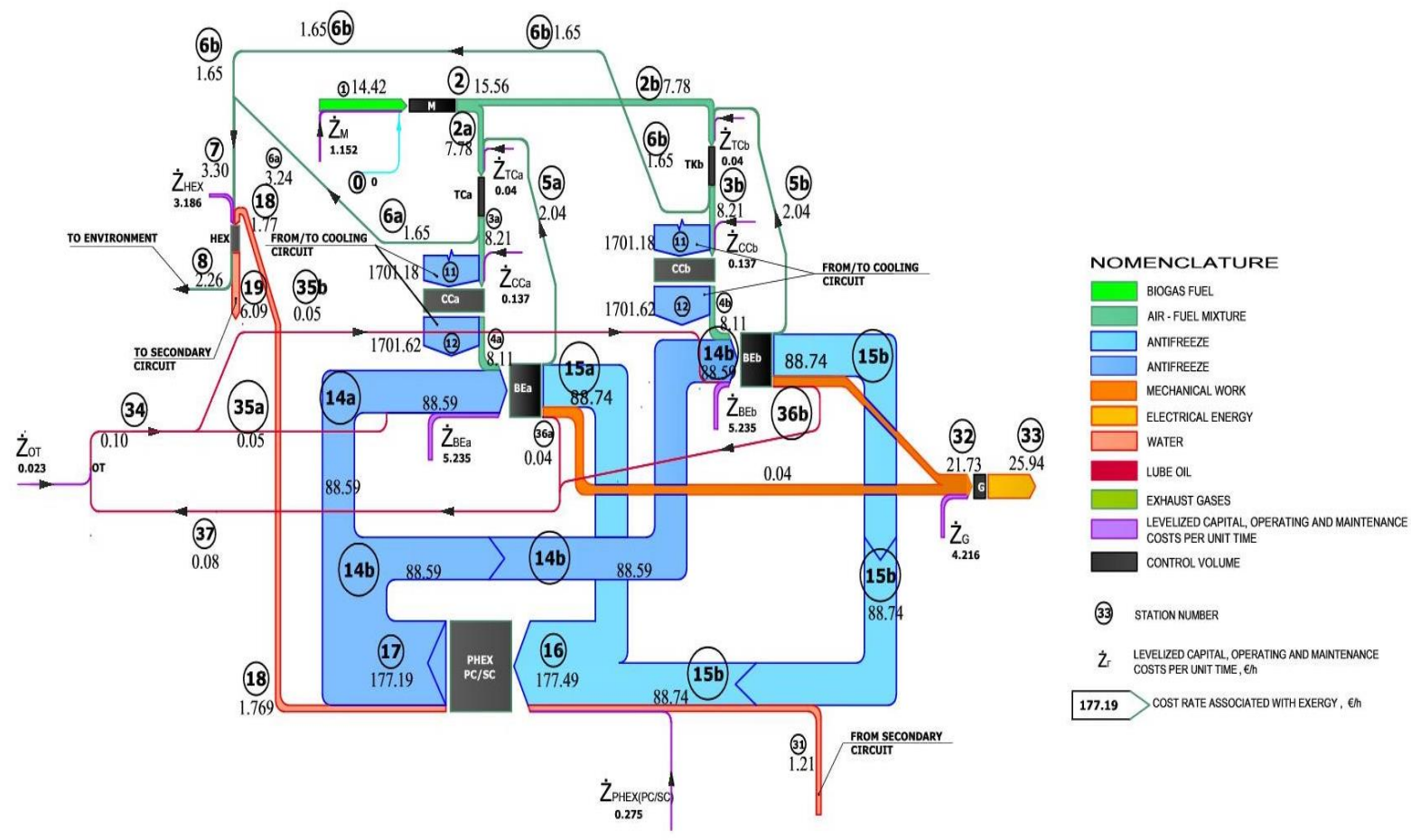

Figure 5. Cost flow diagram of the CHP module (at the summer operating conditions $-T_{0}=298.15 K$,

$$
\left.p_{0}=1.013 \mathrm{bar} \text { and } \varphi_{0}=55 \%\right)
$$


According to the data from Table 4 about the sum $\dot{C}_{D}+\dot{Z}_{k}$, the biogas engines (BEa,b), the generator (G), heat exchanger (HEX) and the air-cooled radiator (ACR) can be considered as the most important system components from thermoeconomic optimization point of view and it remains unchanged at the considered different groups of ambient reference conditions (Figure 6).

Table 4. Thermoeconomic performance parameters at the summer operation condition of the system

$$
\left(T_{0}=298.15 \mathrm{~K}, p_{0}=1.013 \mathrm{bar} \text { and } \varphi_{0}=55 \%\right)
$$

\begin{tabular}{|c|c|c|c|c|c|}
\hline Component & $\begin{array}{c}\boldsymbol{c}_{\boldsymbol{P}}, \\
\boldsymbol{\epsilon} / \mathbf{G J}\end{array}$ & $\begin{array}{c}\boldsymbol{c}_{\boldsymbol{F}}, \\
\boldsymbol{\epsilon} / \mathbf{G J}\end{array}$ & $\begin{array}{c}\dot{\boldsymbol{C}}_{\boldsymbol{D}, \boldsymbol{k}}+\dot{\boldsymbol{Z}}_{\boldsymbol{k}} \\
\boldsymbol{\epsilon} / \mathbf{h}\end{array}$ & $\boldsymbol{f}_{\boldsymbol{k}, \boldsymbol{\%}}$ & $\boldsymbol{r}_{\boldsymbol{k}, \boldsymbol{\%}}$ \\
\hline BEa,b & 22.50 & 7.72 & 7.28 & 69.86 & 190.66 \\
\hline $\mathrm{G}$ & 30.00 & 24.08 & 5.08 & 82.77 & 24.65 \\
\hline HEX & 64.44 & 4.47 & 3.93 & 80.89 & 1345.7 \\
\hline $\mathrm{ACR}$ & 369.44 & 11.22 & 3.56 & 87.43 & 3193.6 \\
\hline HS & 5.28 & 0.42 & 2.18 & 99.92 & 1186.2 \\
\hline M & 6.67 & 6.03 & 1.20 & 95.53 & 8.47 \\
\hline TCC & 490.83 & 44.53 & 1.06 & 37.34 & 1002.6 \\
\hline PHEX CC & 5.56 & 0.42 & 0.92 & 97.92 & 1244.8 \\
\hline PHEX PC/SC & 8.33 & 4.47 & 0.37 & 73.99 & 99.68 \\
\hline WP3 & 1494.44 & 52.83 & 0.21 & 51.0 & 2728.3 \\
\hline CCa,b & 27.50 & 6.53 & 0.18 & 75.47 & 321.9 \\
\hline OT & 13.89 & 4.47 & 0.17 & 14.18 & 209.5 \\
\hline WP2 & 1073.89 & 52.83 & 0.16 & 60.52 & 1932.2 \\
\hline WP1a,b & 1533.33 & 52.83 & 0.15 & 58.20 & 2802.0 \\
\hline TCa,b & 6.67 & 4.47 & 0.14 & 29.04 & 46.35 \\
\hline V & 29.44 & 11.22 & 0.11 & 18.79 & 0.0034 \\
\hline
\end{tabular}

The biogas engines and generator have the highest value of $\dot{C}_{D}+\dot{Z}_{k}$, but their values of the relative cost difference are not among the highest. Furthermore, according to previous studies made by author [6], [33], the exergy efficiency of the generator is very high (96\%), while the exergy destruction of the BEa,b that can be avoided is a small part (18\% of total exergy destruction within this component) due to the source of the thermodynamic inefficient in this unit - the chemical reaction of combustion, which is a high irreversible process. Therefore, the second highest value of the sum $\dot{C}_{D}+\dot{Z}_{k}$ is attributable to the high value of $\dot{Z}_{k}$ for the generator $\left(86.7 \%\right.$ of the sum $\dot{C}_{D}+\dot{Z}_{k}$ ), and not due to cost rate of exergy destruction. It is important to note that by reason of technological limitations (M, TCa,b, CCa,b, OT, BEa,b and G are mounted together to form a single piece of equipment called the CHP module), the capital investment for the generator, constituting the value of $\dot{Z}_{k}$ could not be decreased. It would to be appropriate to investigate, however, how a slightly increasing of the biogas engines exergy efficiency may be affect to the overall cost effectiveness.

The heat exchanger (HEX) and the air-cooled radiator (ACR) are the components having the next highest values of $\dot{C}_{D}+\dot{Z}_{k}$. The high values of $f_{k}$ and $r_{k}$ suggest that it would be cost effective to decrease their capital investments and to increase their exergy efficiencies.

According to the control algorithm of the CHP system, ACR and WP3 are switched on when the temperature of the returned from the digesters water, $\mathrm{T}_{22}$, becomes equal to $68^{\circ} \mathrm{C}$. At the winter ambient reference conditions, the thermal needs of mesophilic fermentation process, occurring within the digesters are high. Thus, the temperature of the returned from the digesters water is below $68^{\circ} \mathrm{C}$ and, as can be seen from Figure 6 , the aircooled radiator is not exploited at the winter operating conditions. Therefore, the heat exchanger (HEX) is the third major component from thermoeconomic optimization point of view. Consequently, if partial load of the CHP modules be changed, the optimum between the thermodynamic and economic system parameters could be achieved. 
It is apparent from Table 4 that the smallest value of the sum $\dot{C}_{D}+\dot{Z}_{k}$ is observed in the water pumps (WP1a,b and WP2), the turbochargers (TCa,b) and the 3-way valve (V). Contribution of these components to the process of cost formation of the products in the CHP system is insignificant.

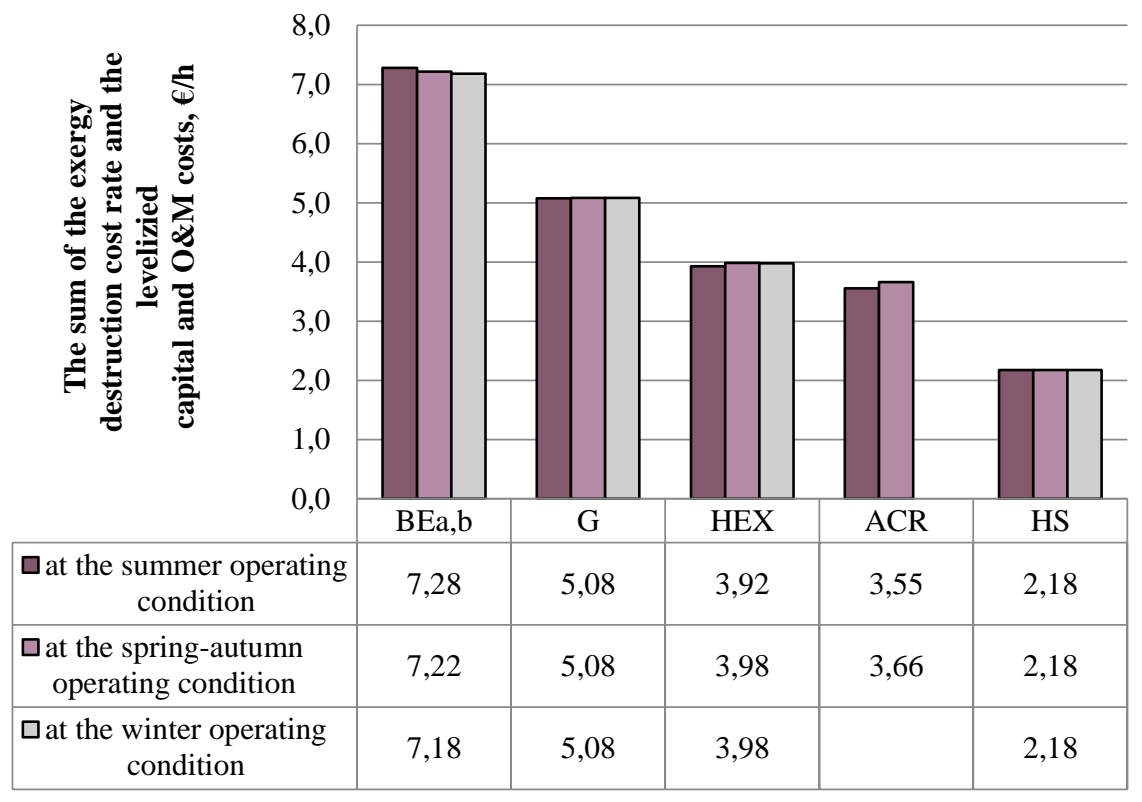

Figure 6. The most important system components from thermoeconomic optimization point of view at different ambient reference conditions

Both thermoeconomic and traditional economic cost analysis ensure the attribution of all system expenditures (capital investment, O\&M costs, fuel cost and etc.) to the costs of electricity and heat produced. Notwithstanding, from the Figure 7 we can see that there is a difference between the results obtained by the two methods.

The analysis of the results presented in Figure 7 reveals that the thermoeconomic cost of produced electrical power relative to cost of thermal energy is comparable to that of market price of electricity to thermal and this statement corroborates the idea of Bagdanaviciusa, Sansom et al. [15], who suggested that the thermoeconomic analysis provides a better estimate of heat value than that from the economic cost analysis. This is because of the fact that the economic analysis does not take into account the quality of the products of the system.

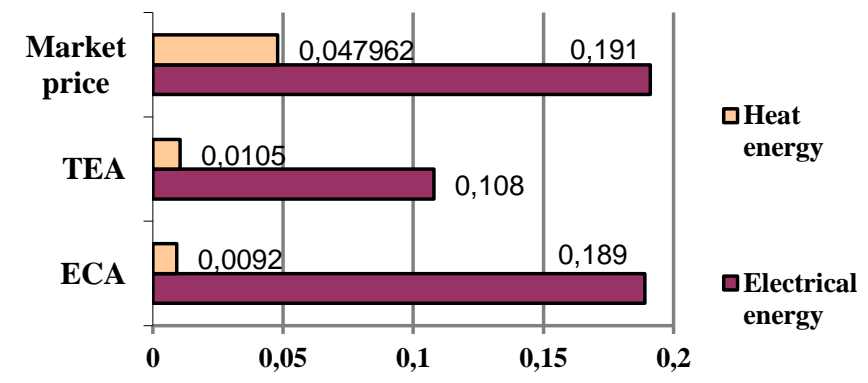

Unit exergy and energy cost of the products, $€ / \mathbf{k W h}$

Figure 7. Comparison of results from economic and thermoeconomic analysis of the biogas CHP system

\section{CONCLUSION}

This paper has explained processes of cost formation in a cogeneration system driven by biogas engines by applying the thermoeconomic analysis based on the SPECO method. One of the more significant findings to 
emerge from this study is that the specific unit exergetic cost of the net electrical power and heat energy produced by the biogas engine driven cogeneration system, situated in Bulgaria are calculated to be $0.11 € / \mathrm{kWh}$ and $0.01 \mathrm{€} / \mathrm{kWh}$, respectively. An issue that was not addressed in this study was how some design parameters have an effect on the cost of the total system product.

Returning to the problems and aims posed at the beginning of this study, it is now possible to state that the thermoeconomic interconnections of the components were defined, and the correct theoretical framework for optimization can be determined. It is clear that, if the optimization objective is to increase the thermodynamic efficiency of the major system components or the overall CHP system on account of declining cost of the system product, it is necessary to find the extremum of a clearly defined function. This function should be expressed as a quantitative relationship between irreversibility of the thermodynamic processes, the capital investment and the O\&M costs of the system components. The obtained results demonstrate exactly the relationship between the monetary costs, exergy destruction and losses within the analyzed CHP system.

Further research should be undertaken to investigate the sensitivity of objective function from changing of the design parameters and after that to perform the optimization of the system, i.e. to search the minimum of the defined above total cost function, $\dot{C}_{t o t}$.

\section{ACKNOWLEDGMENTS}

The author is grateful to the company along with the technical staff, located in the Varna Wastewater Treatment Plant, Bulgaria for the support and the assistance. The author also would like to thank Assoc. Professor Dr. Dimityr Rusev for his valuable advices, brilliant ideas and constructive comments, which have been very useful in conducting of every one author's research.

\section{NOMENCLATURE}

$\dot{C}$ - exergy cost rate, $€ / \mathrm{h}$

$c$ - unit exergy cost, $€ / \mathrm{kWh}$

$C R F$ - capital recovery factor

$E \dot{x}$ - exergy flow rate, $\mathrm{kW}$

$E \dot{x}_{D}$ - exergy destruction rate, $\mathrm{kW}$

$f$ - exergoeconomic factor, $\%$

$n$ - life time of the system, years

$r$ - relative cost difference, $\%$

$\dot{W}$ - work rate or power, $\mathrm{kW}$

$\dot{Z}$ - levelized capital, operating and maintenance cost per unit time, $€ / \mathrm{h}$

$\varphi$ - relative humidity of the air, $\%$

$\tau$ - annual number hours of system operation at $75 \%$ load Subscripts

$\mathrm{D}$ - destruction

e - exit

$\mathrm{F}-$ fuel

i - inlet

$\mathrm{k}-k$ th component

$\mathrm{L}-$ levelized

$\mathrm{L}-$ losses

$\mathrm{P}$ - product

q - heat

tot - total

w - work

ACR - air-cooled radiator

$\mathrm{BEa}, \mathrm{b}$ - biogas engine

$\mathrm{CC}$ - carrying charges

$\mathrm{CCa}, \mathrm{b}$ - cooling charger

CHP - combined heat and power

CI - capital investment

ECA - economic cost analysis

FC - fuel cost 


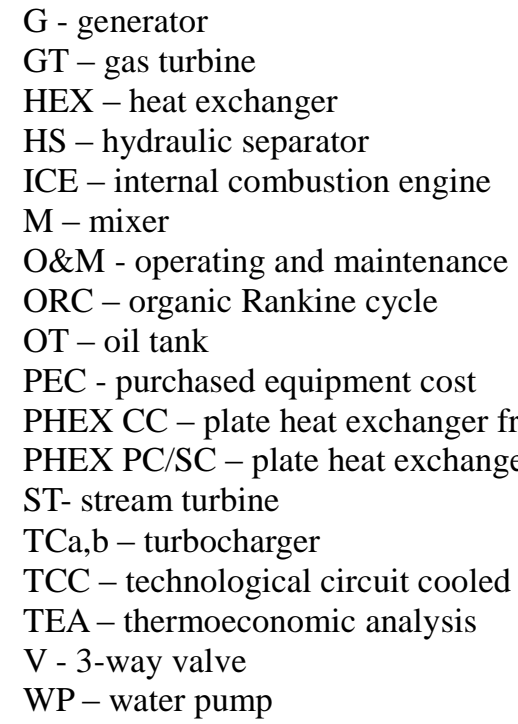

\section{REFERENCES}

[1] Bhatt, M.S. (2000). Energy audit case studies II - air conditioning (cooling) systems. Journal of Applied Thermal Engineering, 20(3), p. 297-307.

[2] Khurana, S., Banerjee, R., Gaitonde, U. (2005). Energy balance and cogeneration for a cement plant. Journal of Applied Thermal Engineering, 22(5), p. 485-494.

[3] Kabir, G., Abubakar, A.I., El-Nafaty, U.A. (2010). Energy audit and conservation opportunities for pyroprocessing unit of a typical dry process cement plant. Journal of Energy, 35(3), p. 1237-1243.

[4] Sun, Z. S. (2008). Energy efficiency and economic feasibility analysis of cogeneration system driven by gas engine, Journal of Energy and Building, 40, (2), 2008, pp. 126-130.

[5] Moran M., Shapiro H. (2006). Fundamentals of Engineering Thermodynamics. 5th ed. England: John Wiley \& Sons Ltd.

[6] Doseva, N., Chakyrova, D. (2015). Energy and exergy analysis of a cogeneration system with biogas engines. Journal of Thermal Engineering, 1, (3), p. 391-401.

[7] Abusoglu A., Kanoglu M. (2009). Exergetic and thermoeconomic analyses of diesel engine powered cogeneration: Part 2 - Application. Journal of Applied Thermal Engineering, 29(2-3), p. 242-249.

[8] Mohammadkhani, F., Khalilarya, S, Mirazaee, I. (2013). Effect of ambient temperature on exergetic and exergoeconomic parameters of a CHP System. Journal of Environmentally Friendly Processes; 1(3), p. 28-37.

[9] Seyyedvalilua, M.H., Mohammadkhani, F., Khalilaryac, S. (2015). A parametric study on exergy and exergoeconomic analysis of a diesel engine based combined heat and power system. International Journal of Engineering, 28(4), p.608-617.

[10] Cavalcanti, E., Motta, H. (2015). Exergoeconomic analysis of a solar-powered / fuel assisted Rankine cycle for power generation. Journal of Energy, 88, p.555-562.

[11] Tempesti, D., Fiaschi, D., Gabuzzini (2012). Thermo-economic assessment of a micro CHP system fuelled by geothermal and solar energy. Proceedings of the $25^{\text {th }}$ international conference ECOS, Italy, Volume III, p.321359.

[12] Palomino, R. G., Nebra, S. Energetic, exergetic and exergetic cost analysis for a cogeneration system integrated by an internal combustion engine, HRSG and an absorption refrigeration system. Proceedings of ESDA04 7th Biennial ASME Conference Engineering Systems Design and Analysis, July 19-22, 2004, Manchester, United Kingdom.

[13] Temir, G., Bilge, D. (2004). Thermoeconomic analysis of a trigeneration system. Journal of Applied Thermal Engineering, 24(17-18), p. 2689-2699.

[14] Balli O., Aras H. (2010). Thermodynamic and thermoeconomic analyses of a trigeneration (TRIGEN) system with a gas-diesel engine: Part II - An Application. Journal of Energy Conversion and Management, 51(11), p. 2260-2271.

[15] Bagdanavicius, A., Sansom, R., Jenkins, N. et al. (2012). Economic and exergoeconomic analysis of micro GT and ORC cogeneration system. Proceedings of the $25^{\text {th }}$ International conference ECOS, Italy, Volume III, p.98-108. 
[16] Mert, M., Dilmaç, Ö., Özkan, S. et al. (2012). Exergoeconomic analysis of cogeneration plant in an iron and steel factory. Journal of Energy, 46(1), p.78-84.

[17] Coplan, C.O., Yesin, T. (2006). Energetic, exergetic and thermoeconomic analysis of Bilkent combined cycle cogeneration plant. International Journal of Energy Research, 30, p. 875-889.

[18] Athari, H., Soltani, S. Mohammad, S. et al. (2014). Exergoeconomic analysis of a biomass post-firing combined-cycle power plant. Journal of Energy, 77, p.553-561.

[19] Bagdanavicius, A., Jenkins, N. (2011). Exergoeconomic evaluation of small scale CHP systems. Proceedings of the 8th International Conference environmental engineering, May 19-20, Vilnius, Lithuania, p. 727-734.

[20] Sotomonte, C., Venturini, O. (2010). Exergoeconomic analysis of small-scale biomass steam cogeneration. Proceedings of 13th Brazilian Congress of Thermal Sciences and Engineering December 05-10, 2010, Uberlandia, MG, Brazil.

[21] Colmenar-Santos, A., Zarzuelo-Puch, G., Borge-Diez,,D., García-Dieguez, C. (2016). Thermodynamic and exergoeconomic analysis of energy recovery system of biogas from a wastewater treatment plant and use in a Stirling engine. Journal of Renewable Energy, 88, p.171-184.

[22] Sung, T., Kim, S., Kim, K. (2017). Thermoeconomic analysis of a biogas-fueled micro-gas turbine with a bottoming organic Rankine cycle for a sewage sludge and food waste treatment plant in the Republic of Korea, Journal of Applied Thermal Engineering, 127, p. 963-974.

[23] Abusoglu, A., Demir, S., Kanoglu, M. (2013). Thermoeconomic analysis of a biogas engine powered cogeneration system. Journal of Thermal Science and Technology, 33(2), p. 9-21.

[24] Bejan A, Tsatsaronis G, Moran M. (1996). Thermal design and optimization. Wiley: New York.

[25]Doseva, N. (2017). Thermoeconomic analysis and optimization of energy systems. Doctoral thesis, Varna Technical University, Bulgaria.

[26] Tsatsaronis, G. (1984). Combination of exergetic and economic analysis in energy conversion processes. Proceedings, European Congress on Economic and Management of Energy in Industry, Portugal, Apr. 2-5, Vol. 1, pp.151-157.

[27] Bonnet, S., Alaphilippe, Stouffs, P. (2005). Energy, exergy and cost analysis of a micro-cogeneration system based on an Ericsson engine. International Journal of Thermal Sciences, 44, p. 1161-1168.

[28] Aras, H., Balli, O., Hepbasli, A. (2008). Exergoeconomic analysis of a combined heat and power system with the micro gas turbine (MGTCHP). Journal of Energy Explore Exploit, 26(1), p.53-70.

[29] Balli, O., Aras, H., Hepbasli, A. (2007). Exergoeconomic analysis of a combined heat and power (CHP) system. Journal of Energy Research, 32, p.273-289.

[30] Shokati, N., Ranjabar, F., Yari, M. (2004). A comparative analysis of Rankine and absorption power cycle from exergoeconomic viewpoint. Journal of Energy Conversion Management, 88, p.675-668.

[31] Kim, S.M., Oh, S.D., Kwon, Y.H. et al. (1998). Exergoeconomic analysis pf thermal systems. Journal of Energy, 23(5), p.393-406.

[32] Arriola, D., Olivera Junior, S. (2013). Tetra-combined trigeneration system. Thermoeconomic analysis. Proceedings of 17th International Congress of Mechanical Engineering.

[33] Doseva, N. (2014). Advanced exergetic analysis of cogeneration system with a biogas engine. Proceedings of the 14th International Multidisciplinary Scientific GeoConference SGEM 2014, Book 4, Vol. 1, p. 11-18. 